\title{
Review on Citrus Triteza Virus
}

\author{
Zenebe Wubshet ${ }^{*}$, Dereje Amare ${ }^{2}$ \\ ${ }^{1,2}$ Msc. Candidate in Plant Pathology Jjimmma Universty College of Agriculture and Veterinary Medicine \\ Department of Horticulture and Plant Science School of Garaguate Studies, Jimma, Ethiopia
}

*Corresponding Author: Zenebe Wubshet, Msc. Candidate in Plant Pathology Jjimmma Universty College of Agriculture and Veterinary Medicine Department of Horticulture and Plant Science School of Garaguate Studies, Jimma, Ethiopia

\begin{abstract}
The genuses Citrus are commercially important fruit crop belongs to Rue family. They are mainly cultivated in the subtropical and tropical regions of the world between $40^{\circ}$ north and south latitude in over 137 countries. However, citrus production has been delayed with biotic and a biotic factors. Mainly, plant viruses are highly prevalent and serious threat to cultivated plants and agricultural production in plants like vegetables and fruits worldwide. Citrus triteza virus (CTV), is the largest and most complex member of the genus Closter virus (family Closteroviridae) that induce the most destructive disease of cultivars and hybrids of citrus worldwide. The only natural non-citrus host that has been reported is Passilora. Natural hosts of CTV remain essentially symptomless when infected by most CTV isolates. To establish a productive infection in a host plant virus needs to be able to move throughout the plant from an initially infected cell. The spatial and temporal spread of CTV in citrus orchards has been studied in different parts of the world. The most common diagnostic symptoms of CTV include Quick Decline, Seedling Yellows and Stem Pitting Disease. The diseaes is economically most important constraints of Citrus production widely, little emphasisahs been given especially in Ethiopia. Exclusion and Quarantine, Resistant/tolerant rootstocks and Vector control are the most common means of CTV management today. Therefore, if we need to use citrus as one income source for the country, future research should give great focus on those viral diseases Like CTV as of other economical diseases as a whole.
\end{abstract}

Keywords: Virus, Vector, Host, Management

\section{INTRODUCTION}

The genus Citrus belongs to the Rutaceae or Rue family, sub-family Aurantoideae. The 5 commercially important fruit crops (sweet orange (C.sinensis .L.) tangerine (C. reticulata B.), grapefruit (C. paradisi M.), lemon (C.Limon. F) and lime (C. aurantifolia L.) are recognized as single species within Citrus. They are mainly cultivated in the subtropical and tropical regions of the world between 400 north and south latitude in over 137 countries on six continents (Ismail and Zhang, 2004).

Plant viruses are highly prevalent and serious threat to cultivated plants and agricultural production in plants like vegetables and fruits worldwide. Viruses have evolved as combinations of genes whose products interact with cellular components to produce progeny throughout the plants and in most cases, to interact with a vector to be moved to other plants. These processes require several layers of precise interactions with the host. In general, the more conserved genes tend to be those whose products interact within the cell to replicate the viral genome (Fanny et a 1., 2015). This process appears to be somewhat generic because many viruses have been found to be capable of multiplying in individual cells (protoplasts) but cannot move throughout the intact plant. The less conserved genes tend to be those that have evolved for interactions with the specific host for movement and to counter host defense systems (Dung, 2006; Lucas, 2006).

Viruses that infect higher plants share a number of common principles with animal viruses. These include virion morphology and strategies for replication and expression of their genomes. Though, to establish a productive infection in the host, plant virus need to be able to move throughout a plant from an initially infected cell (Yokomi et al., 2017). Success depends upon compatible interactions between viral and host factors. Generally, systemic movement is thought to involve two distinct processes: cell-to-cell movement which indicates the process that allows the virus to transverse the 
cell wall between adjacent cells and long-distance movement, which is a process that allows the virus to enter the sieve element from an adjacent nucleated cell and rapidly move through the connected sieve elements, followed by its exit into another adjacent phloem-associated cell at a distal region of the plant(Waigmannet al., 2004; Scholthof, 2005).

Citrus tristeza virus (CTV), a member of the genus Closterovirus (family Closteroviridae) is the causal agent of serious diseases of citrus that is has widely i.e. Almost in all citrus production areas of the world (Moreno et al., 2008). It is the largest identified RNA virus infecting plants and the second largest worldwide. The virus is phloem limited and it is transmitted by aphids (Hemipteraaphididae) and mechanically by graft propagation of virus-infected plant tissues.CTV isolates from different hosts and areas display great variability either biologically or genetically (Albiach,2012).This Virus possess the potential to disrupt host physiology either by usurpation of substantial amount of plant metabolic resources or by the interaction of a specific viral product with the host components and CTV induces three hallmark syndromes plus a myriad different symptom patterns in indexing plants (Culver and Padmanabhan, 2007).

CTV is assumed to have originated in China quite a long time ago. Tristeza, known as 'quick decline' in the United States, is the most destructive disease of citrus in the western hemisphere and has a worldwide distribution (Yokomi et al., 2017). It is the causal agent of devastating epidemics that changed the course of the citrus industry. Adapted to replicate in phloem cells of a few species within the family Rutaceae and to transmission by a few aphid species, CTV and citrus probably coevolved for centuries at the site of origin of citrus plants. CTV is a member of the closterovirus group which have thread-like, flexuous virions, insect vectors, cause characteristic cytopathological structures ( inclusion bodies) in infected phloem tissues, and have a positive sense, single-stranded RNA genome of up to $20 \mathrm{~kb}$ (Marti, 2013).However, the information on the impact and distribution of this virus is quite limted in our country. Therefore, the present review can provide some highlights on the overall status of Citrus Tristeza virus.

\section{Objective}

$>$ To review on the overall status of Citrus Tristeza virus in potential citrus production areas including Ethiop

\section{LITERATURE REVIEW}

\subsection{Taxonomic Position}

Citrus Tristeza Virus is the largest and most complex member of the genus Closterovirus this member of the closterovirus group (Family: Closteroviridae ) have thread-like, lexuousvirions, insect vectors, cause characteristic cytopathological structures (inclusion bodies) in infected phloem tissues, and have a positive sense, single-stranded RNA genome of up to $20 \mathrm{~kb}$. Based on molecular characterization of CTV and other members of the closterovirus group, enough genetic diversity occurs among members to propose that the closteroviruses which contains homologues of cellular heat-shock proteins (Moreno et al., 2008).

The Closteroviridae are composed of three genera: Citrivirus (CTV type member) which has one 19.3 $\mathrm{kb}$ genome component and 12 open reading frames (ORFs); Closterovirus (beet yellows virus type member) which has one $15.4 \mathrm{~kb}$ genome and 9 ORFs; and Biclovirus (lettuce infectious yellows type member) which has two genome components of 8.1 and $7.1 \mathrm{~kb}$ and 9 ORFs (D'onghiaet al., 2009).

Genotypes have diverged from the ancestral population or have arisen through recombination with previously described strains (Harper et al., 2008). CTV populations in citrus trees are quasispecies in nature, so complex mixtures of viral genotypes and defective viral RNAs developed during the longterm vegetative propagation of virus isolates through grafting and the mixing of such isolates with aphid-vectored isolates. This results in CTV isolates containing a population of sequence variants, with one usually being predominant (Moreno et al., 2008)

\subsection{Hosts}

CTV infects all species, cultivars and hybrids of citrus. It also infects some citrus relatives such as Aeglopsis, Afraegle, Fortunellaand Pamburusand some intergeneric hybrids. Species of Passiflorahave been infected experimentally (but not naturally) and are the only non-rutaceous experimental hosts (Barjoseph, et al., 2008) 
The only natural non-citrus host that has been reported is Passilora (Kitajimaet al. 1974).Some of the more important economic hosts are: sweet orange (Citrus sinensis (L.)), grapefruit (C. paradisiMacf.), mandarins (C. reticulata), Blimes([C. aurantifolia (Christm.) Swing.) And C. latifoliaTan.), lemons (C. limon (L.) ,pummelo [C. grandis (L.) Osb.), tangelos [C. reticulata x C. paradise), tangors (C. reticulata x C. sinensis), calamondin (C. madurensisLour.), and kumquat (Fortunella margarita (Lour.) Swing) (Moreno et al., 2008).

Many natural hosts of CTV remain essentially symptomless when infected by most CTV isolates. Mandarins, sweet oranges and rough lemon are among common tolerant hosts. Some citrus species show a selective susceptibility and are readily infected by some CTV isolates and not by others (Martelli et al., 2000).). Poncirustrifoliata (L.) , citrus relative commonly used as a rootstock, is highly resistant to nearly all isolates of CTV and this resistance is also found in some trifoliate orange hybrids (Navaset al., 1995).

\subsection{Citrus Tristeza Virus Genetics and Plant-Host Interactions}

In order to infect a plant, CTV needs to enter in the cell, and to overcome the constitutive and/or inducible plant defences, to re-program the plant cellular machinery for its viral multiplication. The infection process will continue with the assembly of new viral particles that will move cell to cell through the plasmodesmata to colonize the plant systemically. Each CTV gene product seems to have a primary genetic function required for the survival of the virus. However, there are secondary genetic interactions, which cause or trigger resistance or pathogenic responses in the citrus host (Culver et al., 2007; Voinnet, 2005). The genusCitruscontains multitude of species, cultivars and intergenic hybrids, with which CTV could interact causing a range of physiological and biochemical responses. These could be from either pathogenic or asymptomatic phenotypes to limited or complete plant resistance (Moreno et al., 2008).Although most of these mechanisms are The complex genetics of Citrus tristezavirus still a mystery, new discoveries towards the understanding of the genetics of CTV movement in the plant, host-range, host resistance and pathogenicity have been reported recently (Albiach et al., 2010).

\subsubsection{Virus, Vector and Plant Interactions}

Efficiency of CTV transmissibility is affected by the species of aphid, by the source plant at acquisition feeding and the CTV isolate. For instance, cultivars of sweet orange are more suitable for acquisition and more sensitive to infection than grapefruit or lemon seedlings. Grapefruit groves do not tend to undergo decline on sour orange rootstock where there is widespread decline of sweet orange on sour orange root stock. Citrus aphids have a preference only for young lemon seedlings above sweet orange or young grapefruit seedlings. There is also a recognized decrease in transmission from plants kept at higher temperatures compared with a marked decrease in virus concentration in controlled experiments (Bhandari and Sharma, 2018). Red grapefruit varieties present problems with cross protection due in part to the slow distribution of protecting CTV isolates throughout the plant (Broadent, 1995; Ng, 2006). Pigmented grapefruits are more sensitive to stem pitting symptoms than14 non-pigmented grapefruit (and grapefruit also have been shown to influence the strain composition of CTV isolates (Van Vuuren and Van der Vyver, 2000)

\subsection{Movement in Host and Systemic Infection}

To establish a productive infection in a host a plant virus needs to be able to move throughout a plant from an initially infected cell. Success depends upon compatible interactions between viral and host factors. Generally, systemic movement is thought to involve two distinct processes: cell-to-cell movement, which is a process that allows the virus to transverse the cell wall between adjacent cells, and long-distance movement, which is a process that allows the virus to enter the sieve element from an adjacent nucleated cell and rapidly move through the connected sieve elements, followed by its exit into another adjacent phloem-associated cell at a distal region of the plant (Ilharco et al., 2005). A major obstacle for the spreading virus is to cross the boundaries represented by the cell wall. For this purpose most viruses utilize specific virus-encoded movement proteins as well as some host proteins that facilitate their translocation through plasmodesmata channels. The viral proteins and their interactions with the host during cell-to-cell movement are fairly well-known (Waigmann et al., 2004; Scholthof, 2005; Lucas, 2006).

Despite the fact, CTV dispersal between new areas or countries occurs by graft propagation of virus 
infected plant tissues; aphid transmission is responsible of local spread. Viruliferous aphids of Toxopteracitricida (Kirkaldy) and Aphis gossypii (Glover) species are able to transmit CTV in a semipersistent manner . The aphid $T$. citricidais the most effective transmitting CTV and the most efficient and fast in the spatial and temporal viral spreading in citrus orchards(Moreno et al., 2008).

Factors affecting aphid transmission include isolate or strain differences of the virus, the aphid species, plant donor and receptor varieties, the environmental conditions, and the number of aphid's involved. In addition, specific isolates or strains of CTV in mixtures may not be equally distributed throughout the source plant, further reducing the likelihood of successful transmission. Finally, aphids show a marked preference for some citrus species over others, for example it has been observed in feeding choice experiments that Aphis gossypii preferentially infests mandarins or sweet oranges over lemons (D'Ursoet al., 2000).

\subsection{Citrus Tristeza Virus Suppressing Genes of Plant Silencing Mechanism}

Plants constitutive defense consists of the RNA mediated post-transcriptional silencing mechanism (PTGS) that implies the specific degradation of the viral dsRNA in small interfering RNAs (siRNAs), which guides a specific plant ribonuclease to disintegrate the viral genomes in the cytoplasm. Besides the antiviral role, the plant silencing mechanism has important functions in regulating plant gene expression (miRNA metabolism). In order to infect plants, viruses developed a strategy to block this silencing mechanism: the suppressing genes. This strategy allows viral replication but interfere with host gene expression, thus inducing disease (Qu, \& Morris, 2005). As indicated previously, CTV evolved ending up with three proteins that are 12 Current Issues in Molecular Virology. Viral genetics and BiotechnolViruses possess the potential to disrupt host physiology either by usurpation of substantial amount of plant metabolic resources or by the interaction of a specific viral product with the host components. Therefore, the degree of severity of a specific CTVisolate, strain or genotype usually is assessed by using indexing plants (Culver et al., 2007).In this case, the degree of CTV symptom logy ranges from the mild phenotypes, which are almost asymptomatic, to highly virulent CTV isolates that could generate vein clearing, leaf cupping, dwarfing, stem pitting and the plant death (Moreno et al., 2016). This diversity and grade of symptom responses to CTV infection suggests the possible presence of more than one mechanism of pathogen city taking place during the CTV Citrus interactions (Moren et al., 2008).

\subsection{Epidemiology, Transmission and Spread}

The spatial and temporal spread of CTV in citrus orchards has been studied in different parts of the world. These studies provide evidence for the fact that a long period of time may elapse between the introduction of a primary source of CTV inoculum and the development of a tristeza disease epidemic (Gottwald et al., 2002)

Tristeza apparently originated in Asia and existed there for many years in tolerant cultivars which were either propagated vegetatively as cuttings or by seed. New areas of citri culture in other continents were first established from seed and were free of CTV infection. Subsequently, CTV has been introduced into nearly all citrus-growing areas via virus-infected budwood or plants. In many areas infections have become wide spread due to propagation and secondary spread by aphids. In some areas little or no secondary spread has occurred from the few existing infected trees (Timmer et al., 2000)

Primary infections of CTV are usually established via propagation of infected plants and propagation of virus infected buds is the cause of dispersal of CTV into new areas, while the aphid vector is responsible for local spread. Epidemics of CTV decline observed in many countries began with importation and propagation of infected plants in areas heavily planted with CTV-free trees on sour orange (Bhandari and Sharma, 2018). When efficient vectors were present epidemics of decline often followed. Although CTV epidemiology is significantly affected by the citrus cultivar and horticultural practices, the most important factors are the CTV isolate and the aphid vector. When T. citricidais present, temporal and spatial spread of CTV spread is increased (Garnsey et al., 1996). This aphid has a narrow host range and migrants move from citrus to citrus to start new aphid colonies and, in this process, can transmit CTV if they are viruliferous. High aphid populations also coincide with new lush who is favorable for virus acquisition and inoculation. The other vectors are much less efficient than T. citricida and also have a wider host range. Migrants may originate in other crops prior to feeding on citrus and mayfeed on a different plant species after leaving citrus (Moreno et al., 2016). 
Therefore, aphid host range and feeding behavior likely affect pattern and rate of spread (Gottwald et al., 1996). It is assumed that aphid population levels may be correlated with rates of spread, but threshold levels for minimum and maximum levels of transmission have not been established. Natural spread is generally slow in desert regions where natural thermotherapy may keep inoculum at lower levels in plants and may vary seasonally in temperate areas as well. CTV spread rate in sweet oranges is generally higher than that observed in grapefruit (Folimonovet, 2007). CTV isolates in Meyer lemon and some mandarins have not spread appreciably from these hosts unless $T$. citricidais present. The latent periods between inoculation and systemic infection and between Citrus Tristeza Virus and Toxopteracitricidus: a serious threat to the Mediterranean citrus industry 27 infections and symptom expression also affect evaluation of disease development. Presence of other strains may also inluence rate of virus movement (Tatineni et al., 2008)
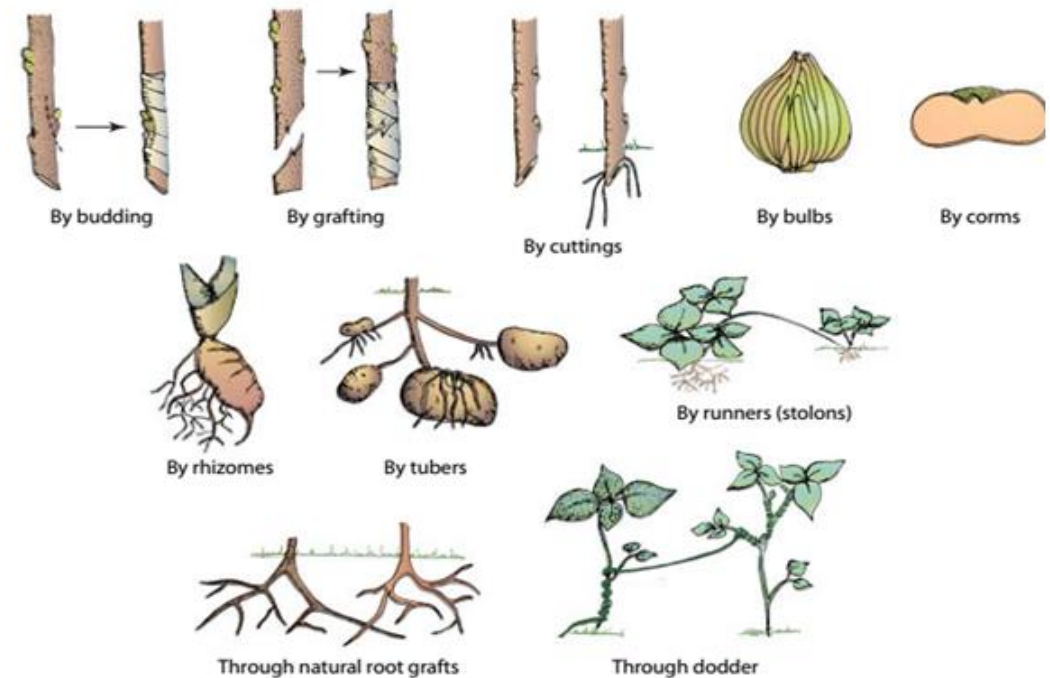

Figure1. General means of transmissions of viruses amon different hosts

\subsection{Diagnostic Symptoms of CTV}

Citrus Tristeza virus (CTV) particles occur in large numbers in phloem cells of Citrus and other members of the Rutaceae, Passifloraspecies being the only nonrutaceous hosts. CTV is generally reported as limited to the phloem cytoplasm and also to the young cortex shoot tissue of plants. When tissue preparations are stained, aggregates of virus particles or inclusion bodies are often found as purple stained, cross-banded 'chromatic cells' in the parenchyma-like cells adjacent to the sieve tubes in pollen. Such inclusions have also been associated with the cambium of newly developing stem cells in the ground meristems (Moreno et al., 2016). Where this association is known to occur, xylem and phloem mother cells are not initiated that are the regions of the 'pits whichlater develop in the stems of infected trees. Necrosis at the bud union is a result of destruction of the phloem tissues in scions grafted onto sour orange rootstock which are undergoing 'quick decline' (Yokomi et al., 2017; Bhandari and Sharma, 2018).

CTV causes different symptoms on citrus plants depending on the virus strain (Fig 2), the variety of citrus, and the scion-rootstock combination. In Asia, various strains of CTV, generally referred to as seedling yellows (CTV-SY), tristeza (CTV-T), stem pitting (CTV-SP), and a mild type, have been widespread for many years. Any of these strains may existence in a citrus plant, or they may occur together, as a complex. The virus is phloem limited and can be detected in leaves, stems, fruits, and roots. Greatest concentrations of virions are found in young growth under relatively mild temperature conditions (Albiach, 2012).

The tristezasyndrome, induced by CTV, has devastated entire commercial citrus industries around the world, since it has caused the death of hundred million trees worldwide. In point of fact, this virus is present in most of the citrus producing areas infecting nearly all species, cultivars and hybrids of Citrus spp. and related genera. Phenotypic ally, CTV induces different grade and wide range of symptoms in Citrus species (Moreno, 2008).

Trees grafted on sour orange root stocks usually show die back and defoliation, stunting and in many cases complete decline. This symptomatology is caused by the starvation of the roots as a 
consequence of sieve-tube necrosis induced by the virus below the bud union. Cells of the modularly rays of the wood become lignified in this area and produce the symptom called inverse pitting, honey combing or pinholing. However, this symptom is not specific to tristeza and can also be induced by Spiroplasma citric (stubborn disease) (Yokomi et al., 2017; Bhandari and Sharma, 2018)

\subsubsection{Quick Decline, or Tristeza Disease}

Symptoms appear a year or more after infection and may occur gradually over several years or very suddenly (QD).Canopy symptoms are wilting, chlorosis and an abnormal crop of small fruit which may persist after tree death in trees affected by QD (Fig. 2A). Clinical symptoms can often be seen by removing a patch of bark across the bud union. Trees which decline slowly usually will have thicker bark immediately below the union and the face of the bark surface below the union will have 1many small conical pits (honeycombing) corresponding to bristle-like protuberances from the wood (Schneider, 1954).Tristezadisease or QD syndrome consists in overgrowth of the scion at the bud union, loss of root mass, and therefore death of citrus commercial varieties grafted on sour orange rootstock (Moreno et al., 2008; Yokomi et al., 2017).

\subsubsection{Seedling Yellows}

The SY syndrome is characterized by stunting (Fig. 2F), leaf chlorosis and sometimes a complete cessation of growth on sour orange, grapefruit or lemon seedlings. Although, SY syndrome might be found at the field in top-grafted plants and it is not economically valuable, it could be examined in the greenhouse in a timely manner and has a substantial diagnostic value for CTV pathotype differentiation. Self-rooted trees of sour orange, Natsudaidai, lemon and buntan are affected by this disease after being infected with CTV-SY. These trees become yellow and die back. If the affected trees are grafted onto a resistant rootstock, they soon recover (Bhandari and Sharma, 2018).

\subsubsection{Stem Pitting Disease}

CTV may also induce stem pitting, stunting and low yields on susceptible cultivars (mainly limes, grapefruits and some sweet oranges) even if they are grafted on tristeza tolerant rootstocks (Fig 2C and E). The cultivars affected and the intensity of the symptoms depends on the virus strain. Some severe strains may induce stem pitting in most citrus cultivars. Stem pitting does not kill trees, but affected trees may have thin canopies and produce fewer fruit of reduced size and quality (Marais $e t$ al. 1996). Dieback occurs in severely affected limes. Chronically infected trees sometimes show a bumpy or ropy appearance of trunks and limbs on larger trees. The twigs and limbs are brittle and easily broken (Albiach et al., 2012).

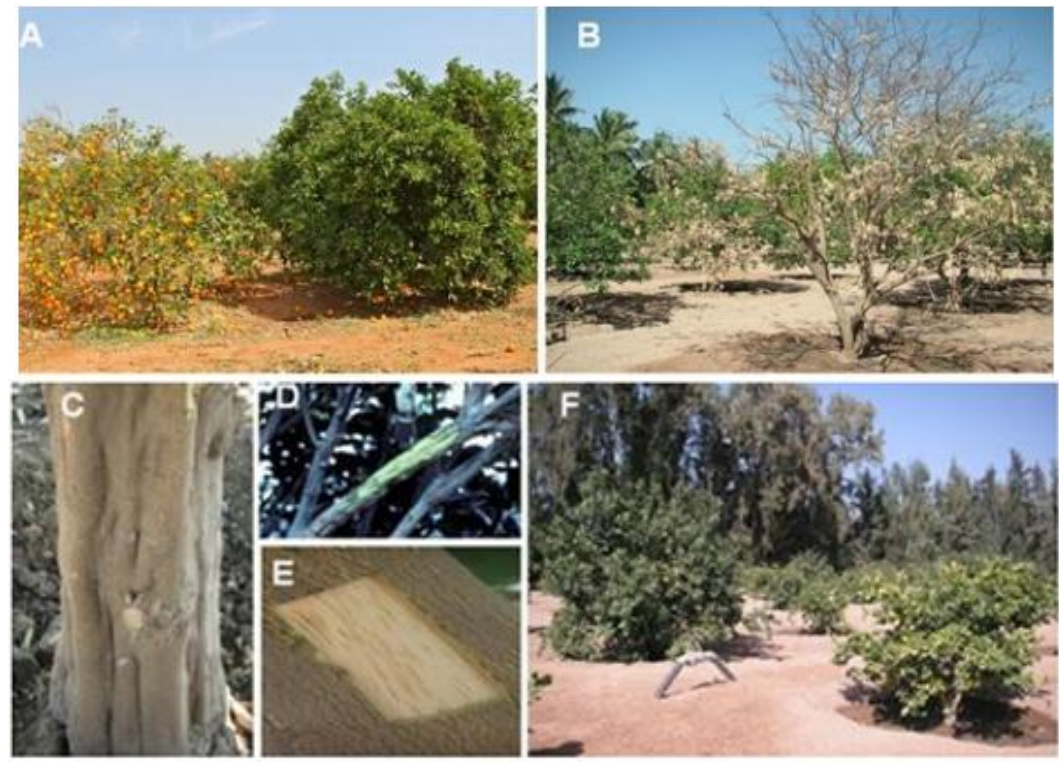

Figure2. Symptoms of citrus triteza virus(CTV) infection: (A) triteza syndrome or decline of sweet orange grafted on sour orange infected with CTV (left) and symptoms less tree (right); $(B)$ collapse or quick decline grafted grapefruit on sour orange; $(C)$ stem pitting on the trunk of grape fruit grafted on Troyer citrange caused by an aggressive CTV strain; $(D)$ sever stem pitting on the branches of grape fruit; $(E)$ stem pitting on the trunk of sweet orange grafted on Cleopatra mandarin and $(F)$ pronounced stunting of CTV infected sweet orange trees grafted on Carrizo citrange (right) compared with a healthy tree (left) (Moreno et al., 2016). 


\subsection{Economic Importance}

CTV is the most economically important virus pathogen of citrus worldwide. It is estimated that worldwide there are over 200 million trees on sour orange rootstock which are at risk to this disease. Sour orange is popular because it produces a vigorous tree with high quality fruit, is adaptable to many soil conditions including high lime and salt content and has tolerance to many other viruses, viroids, and virus-like pathogens and Phytophthora. Use of tristeza-tolerant rootstocks often risks losses from other factors (Yokomi et al., 2017; Bhandari and Sharma, 2018). In addition to decline, many severe CTV isolates cause stem pitting diseases of susceptible scionscultivars and these occur even when tolerant rootstocks are used. Stem pitting weakens trees and eventually reduces fruit size, quality, and quantity (Yokomi et al., 2017; Bhandari and Sharma, 2018). Grapefruit and lime are very sensitive to stem pitting. Sweet orange is more tolerant but can be severely affected by some isolates.

\subsection{Management Options of CTV}

Management/Control strategies for CTV differ according to the incidence and severity of the CTV isolates in an area and with the cultivars and rootstocks used. No single control strategy is applicable in all situations (Garnsey et al., 1996; Lee et al., 1994).

\subsubsection{Exclusion and Quarantine}

Effective quarantine and budwood certification programmes are the best measures to avoid CTV introduction or dispersal in CTV-free areas where citrus are still propagated on sour orange rootstock (Navarro et al., 2002). Elimination of infected trees is the best means to avoid or delay an epidemic When CTV is absent or rare, preventive efforts should be made to avoid introduction of CTV into the growing area by having quarantines on importation of live citrus tissue. A practical and safe method to legally introduce cultivars from other regions and to free these of infection is necessary and reduces industry pressure to illegally introduce new cultivars or germplasm resources. Procedures for safe international movement of citrus germplasm have been devised. Careful control of propagating material remains the single most effective means to avoid rapid and extensive CTV epidemics. If a few trees become infected in a CTV-free area and indigenous aphids are poor vectors, natural spread can be slowed appreciably by a vigilant eradication and suppression program. However, an effective survey program is essential and when CTV is detected, infected trees must be removed immediately and surveillance maintained (Garnsey et al., 1996; Gottwald et al., 2002).

\subsubsection{Resistant/Tolerant Rootstocks}

There are different Citrus species and relatives that exhibit total or limited resistance to CTV infection. Pummelos, sour orange and the rootstock Swinglecitrumelo display a differential degree of resistance depending on the CTV strain (Moreno et al.,' 2008).Resistance of plants to viruses' results from blockage of a basic step in the virus life cycle. This blockage can result from the lack of a factor(s) in the plant that is necessary for virus multiplication and movement (passive resistance) or activation of a defense mechanism (active resistance) (Culver and Padmanabhan, 2007).

Numerous rootstocks are tolerant or resistant to CTV decline and use of these is essential for economic production of citrus in many areas. Some examples are Cleopatra and Sunki mandarins, rough lemon, Rangpur lime, trifoliate orange and trifoliate orange hybrids such as Troyer and Carrizo citranges and Swinglecitrumelo. CTV resistant/tolerant rootstocks are often susceptible to other problems such as citrus blight, viroids, nematodes, or poor soil conditions (Yokomi et al., 2017).

Breeding to incorporate resistance genes in commercial cultivars is considered the best approach to avoid crop losses due to pathogens. However, different features of citrus biology, particularly their complex genetics and reproductive biology, together with their large plant size have greatly impaired genetic improvement through conventional breeding (Bhandari and Sharma, 2018).

\subsubsection{Vector Control}

Vector suppression is an unproven strategy or C TV control. In the case of semi-persistently transmitted viruses, viruliferous winged aphids may inoculate citrus trees several kilometers from the donor tree. It is not clear what level of vector control is necessary to reduce spread of CTV. However, vector control may have potential to reduce secondary spread (Gourmet et al., 1994). Biological controls to restrict build up of citrus aphids, especially $T$. citricida, may be feasible (Tang and Yokomi, 1996). Although insecticides may not act quickly enough to prevent primary infection by viruliferous aphids, they could reduce local aphid populations and decrease rate of secondary spread. 
Plants have evolved an RNA silencing process, one function of which is to protect them against viruses (Dunoyer and Voinnet, 2005; Wang and Metzlaff, 2005).

\subsection{Tristeza Diseases in Ethiopia}

Citrus (Citrus spp.) is one of the most economically important fruit crops grown by smallholders and commercial farmers in Ethiopia (Kassahun et.al, 2006; Mohammed, 2007). The total area coverage and the annual production of citrus were estimated 5,947 ha and 77,087 tons, respectively (CSA, 2011 and 2012). Citrus farming in Ethiopia is a mixed agriculture in which, many horticultural, field and forage crops, and shade trees are grown with and around citrus plantings. However, citrus production and productivity in Ethiopia is seriously threatened by various diseases including leaf and fruit spot disease (Mohammed, 2007; Sisay, 2007), which is caused by the fungus Pseudocercosporaangolensis (Pretorius et al., 2003).

The land holdings of citrus orchards surveyed varied from 0.15 ha by the smallholder farmer's to10, 030 ha for Bebeka Coffee Estate farm. The area coverage of citrus plantation for these orchards ranged from a few citrus trees in the backyards of smallholders to 1,000 ha at Nura Era citrus farm. Different citrus species and varieties are cultivated in the country. The information obtained from the surveys showed that sweet orange, mandarin, lime, lemon, grapefruit, citrus hybrids, sour orange and citron were produced (Tsedeke, 2008).

According to Sisay (2007) report, Citrus trees that were grown by smallholder farmers were directly from seeds and were not grafted. However, citrus trees in state and private owned orchards, government nurseries and research foundation blocks were grafted. The original sources of scions and rootstocks of most old orchards were unknown, but 33.3\% of the respondents did not have available information. The lack of information in this regard could complicate management and breeding programs aimed at improving citrus production However, the major sources of the recent citrus plantations included University of California at Riverside, MelkaSedi Farm in the Middle Awash, Upper Awash Agro Industry Enterprise, Research Centers, ICRISAT, and local growers. The most commonly used rootstocks were Sour orange, Volkameriana and Troyer Citrange.

In Ethiopia, citrus trees have been afflicted due to different diseases incited by many fungi, bacteria, viruses and virus-like organisms. Viruses and virus-like diseases including psorosis, tristeza and greening were reported to be of great economic importance and thought to play a significant role in the decline of citrus plantation in the country canker, caused by a bacterium, is a serious disease of most commercial citrus cultivars and some citrus relatives Based on field observations citrus producers had reported $13.6 \%$ of citrus trees dieback due to virus problems and over $35 \%$ citrus attack by other plant pathogens in the major citrus farms across Ethiopia (Schubert and Miller, 2000; Sisay, 2007).

Accourding to Tsedeke(2008) Tristeza and greening are among the most important and widely distributed diseases of citrus in many citrus growing regions of Ethiopia. His survey result showedthat three aphid species, viz.A. gossypii, T.aurantii, T.citricidusand the citrus psyllid erytreaearethe only insects that occur as vectors of citrus diseases in Ethiopia. Their geographic distribution and population densities (Table1). Among the aphids recorded A. gossypiiwas the least common species on citrus. It was observed at Arba Minch, Dire Dawa, ErerGota, MelkaWerer and Gibe; it was notrecorded above $1250 \mathrm{~m}$. On the other hand, T. aurantii, is the commonand most widely distributed aphid species in thecountry. It was found in large numbers almost in all altitudes covered inthe survey. T.citricidus, which is known to be the more efficient vector of tristeza virus was restricted to the middle and upper Awash valley, almost all of which lies below $1500 \mathrm{~m}$. In these areas both species of Toxopteramay occur in the same orchard or even on the same tree, but T. aurantiiwas by far the more dominant species.

Table1. The distribution and population density of insect vectors of citrus diseases in Ethiopia

\begin{tabular}{|c|c|c|c|c|c|}
\hline Locality & Altitude (m) & $\begin{array}{c}\text { Aphids- } \\
\text { gossypii }\end{array}$ & Toxomtraaurantii & $\begin{array}{c}\text { Toxoptera- } \\
\text { citricidus }\end{array}$ & Triozaertreae \\
\hline Addis Ababa & $2280-2400$ & - & - & - & +++ \\
\hline Ambo area & $2130-2400$ & - & - & - & +++ \\
\hline Gonder (aba Samuel) & 2040 & - & ++ & - & +++ \\
\hline Indibr & 2040 & - & - & - & +++ \\
\hline Meteakesha & 2000 & - & - & - & +++ \\
\hline
\end{tabular}

International Journal of Research Studies in Agricultural Sciences (IJRSAS) 


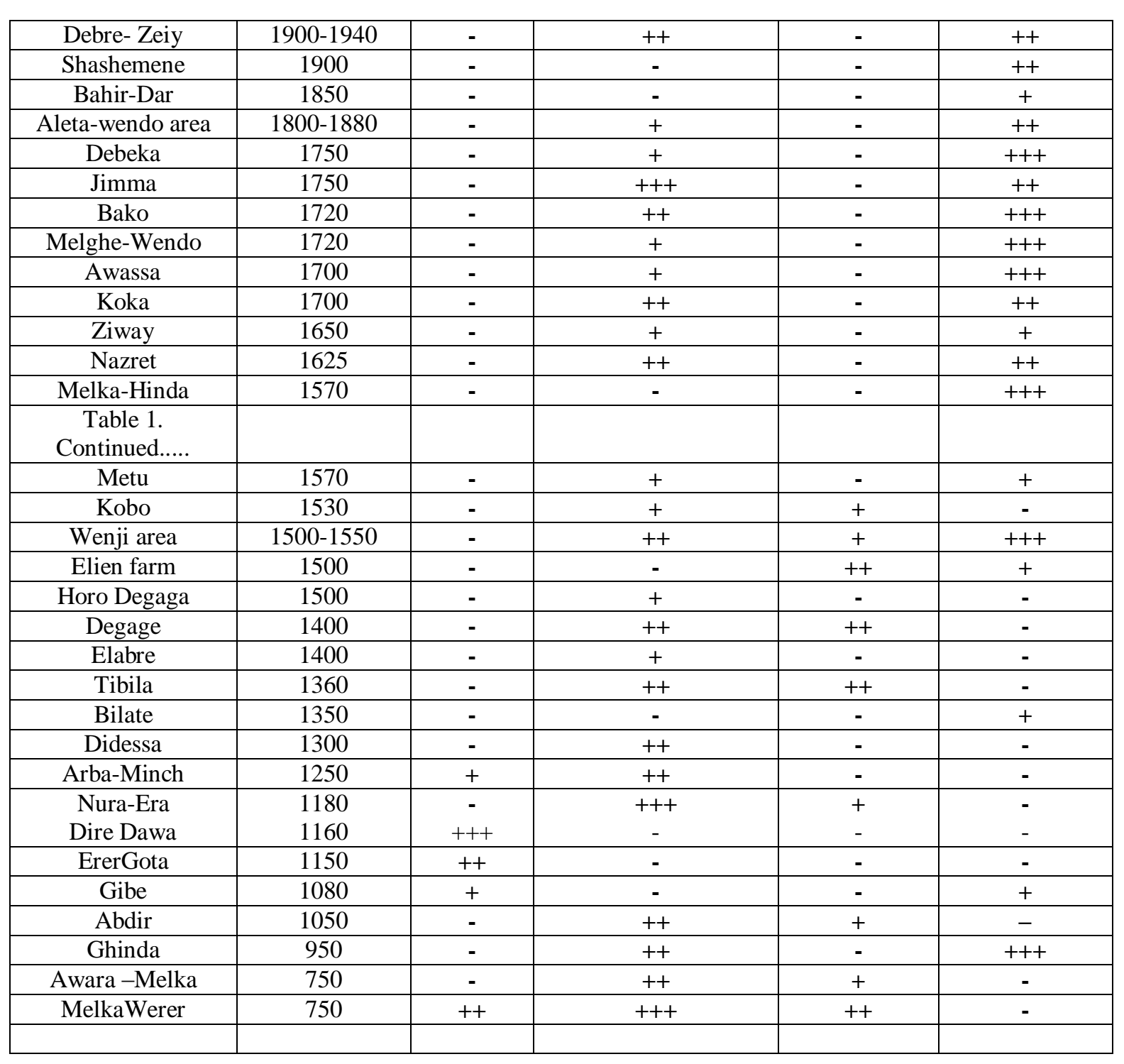

NB: $(-)=$ none, $+=$ light,++ moderate,$+++=$ heavy (Tsedeke, 2008)

Table2. The host range of in sect vectors of Citrus in Ethiopia

\begin{tabular}{|c|c|c|c|c|c|}
\hline Host & Family & $\begin{array}{c}\text { Aphids } \\
\text { gosypyii }\end{array}$ & Toxomtraaurantii & Toxomptarcitricidus & Triozaertreae \\
\hline Abutionlongicuspe & Malvaceae & + & - & - & - \\
\hline Bougainevilleaglabra & Nyctaginaceae & + & - & - & - \\
\hline Capcicumfrutescens & Soanaceae & + & - & - & - \\
\hline Carissa edulis & Apocynaceace & + & - & - & - \\
\hline Citrullus vulgaris & Cucurbitaceae & + & - & + & - \\
\hline Citrus & Rutaceae & + & + & - & + \\
\hline Clausenaanisata & Rutaceae & - & - & - & - \\
\hline Coffea arabica & Rubaiaceae & - & + & - & - \\
\hline Coffea canephora & Rubaiaceae & - & + & - & - \\
\hline Cucumismelo & Cucurbitaceae & + & - & - & - \\
\hline Cucurbita pepo & Cucurbitaceae & + & - & - & - \\
\hline Dovyalisabissinica & Flacuourtiaceae & - & + & - & - \\
\hline D.caffra & Flacuourtiaceae & - & + & - & + \\
\hline Ficussycomorus & Moraceace & + & - & - & - \\
\hline Gossypiumhirsutum & Malvaceae & + & - & - & - \\
\hline Hibiscus escufentus & Malvaceae & + & - & - & - \\
\hline Magnifera indica & Anacardiaceae & + & + & - & - \\
\hline Punicagrantum & punicaceae & + & - & - & + \\
\hline Pygeumafricanum & Rosaceae & - & - & & - \\
\hline
\end{tabular}




\begin{tabular}{|c|c|c|c|c|c|}
\hline Solanummelongeta & Solanaceae & + & - & - & - \\
\hline S.tuberosum & Solanaceae & + & - & - & - \\
\hline Stephaniaabyssinica & Menispermaceae & - & - & - & + \\
\hline Thea sinensis & Theaceae & - & + & - & - \\
\hline
\end{tabular}

NB: $(-)=$ none, $+=$ light,++ moderate,$+++=$ heavy (Tsedeke, 2008)

\section{SUMMARY AND CONCLUSION}

CitrusTristeza virus (CTV) is globally devastating disease of citrus caused by an infectious filamentous closteroviruswhich is phloem limited; aphid vectored and can be harbored asymptomatically in many citrus species. The virus has a very large single-stranded RNA genome, is not mechanically transmitted and has been inadvertently spread to most citrus growing areas through the historical movement of propagative material.

There are three major economically devastating symptoms caused by CTV. The first is a rapid decline and death of trees on sour orange (Citrus aurantiumL.) rootstock. The second is stem pitting of scions regardless of rootstock causing reduced fruit production. Many species of aphid transmit CTV in a semi persistent manner, and this is important in the temporal and spatial spread of the virus within regions and the third one is seedling yellows (SY) syndrome is characterized by stunting, leaf chlorosis and sometimes a complete cessation of growth on sour orange ToxopteracitricidaKirkaldy, the Brown citrus aphid (BrCA), feeds and breeds mainly on citrus, is considered the most efficient vector of CTV. It is economically important virus that challenges citrus production in all citrus producing counties including Ethiopia. However, its identity, economic importance and diagnostic procedures is not well studied in Ethiopia.

Management strategies for CTV usually involve shoot-tip grafting and thermotherapy, certification and eradication programs, deployment of tolerant cultivars or mild strain cross-protection. Vector control is the main strategy of to eliminate the devastating of effects of CTV because the most efficient infection of the virus is viz vectors.

Generally, in Ethiopia citrus production is economical but production and quality deminitionig time to time especially due to these biotic agents like virus. Moreover, no research information regarding these pathogens especially viruses like CTV which implies that little concern is given to viral disease i.e knowledge and proper (scientific) identification of diseases and disorders is very limited in Ethiopia concerning to those viral pathoges causing those viral diseases. So, if we want to boost citrus production in our country, the future research focus must be towards theses potential viral diseases caused by viral pathogens.

\section{REFERENCES}

[1] Albiach, M.R., Guerri, J., Cambra, M., Garnsey, S.M. and Moreno, P., 2000. Differentiation of citrus tristeza virus isolates by serological analysis of p25 coat protein peptide maps. Journal of virological methods, 88(1), pp.25-34.

[2] Albiach, M. R., 2012. Molecular Virology and Pathogenicity Determinants of CitrusTristeza Virus. In Garcia ML. Romanowski V (ed). Viral Genomes. Rijeka: InTech., Available from www.intechopen.com, 275-302

[3] Asins, M.J., Bernet, G.P., Ruiz, C., Cambra, M., Guerri, J. and Carbonell, E.A., 2004. QTL analysis of citrus tristeza virus-citradia interaction. Theoretical and Applied Genetics, 108(4), pp.603-611.

[4] Bar-joseph, M, \& Dawson, W. O.,2008. Citrus tristeza virus. In Encyclopedia of Virolo-gy, Third edition evolutionary biology of viruses. Elsevier Ltd., 1, 161-184.

[5] Bhandari, A.S. and Sharma, N., 2018. Unraveling Pathogenic Behavior of Phytopathogens through Advanced Molecular Techniques. Molecular Techniques in Food Biology: Safety, Biotechnology, Authenticity and Traceability, p.27.

[6] Broadbent, P., Brlansky, R. H., and Industo, J., 1996. Biological characterization of Australian isolates of Citrus tristeza virus and separation of subisolates by single aphid transmissions. Plant Dis. 80,329-333.

[7] Cambra, M., Gorris, M. T., Marroquin, C., Román, M. P., Olmos, A., Martínez, M. C., de Mendosa, H. A., López, A., and Navarro, L., 2000. Incidence and epidemiology of Citrus tristeza virus in the alencian community of Spain. Virus Res. 71, 85-95

[8] Che, X., Mawassi, M. and Bar-Joseph, M., 2002. A novel class of large and infectious defective RNAs of Citrus tristeza virus. Virology, 298(1), pp. 133-145. 
[9] CSA (Central Statistical Agency), 2012. Agricultural sample survey: report on area and production of major crops for private peasant holding, Vol. 1. Statistical Bulletin. CSA, Addis Ababa, Ethiopia.

[10] CSA (Central Statistical Agency), 2011. Agricultural sample survey: large and medium scale commercial farms. Vol. 8. Statistical Bulletin 505. CSA, Addis Ababa, Ethiopia.

[11] Culver, J. N, \&Padmanabhan, M. S., 2007. Virus-Induced Disease: Altering Host Physiology One Interaction at a Time. Ann. Rev. Phytopathol., 45, 221-243

[12] D'Onghia A.M. (ed.), Djelouah K. (ed.), RoistacherC.N. 2009. Citrus tristeza virus and Toxopteracitricidus: a serious threat to the Mediterranean citrus industry. Pp. 19-33

[13] Dunoyer, P. and Voinnet, O., 2005. The complex interplay between plant viruses and host RNA-silencing pathways. Current opinion in plant biology, 8(4), pp.415-423.

[14] Folimonov, A. S, Folimonova, S. Y, Bar-joseph, M, \& Dawson, W. O., 2007. A stable RNA virus-based vector for citrus trees. Virology, , 368, 205-216Cambra M, Gorris M T, Marroquín C, Román M P, Olmos

[15] Garnsey S.M., Gottwald T.R., Yokomi R.K., 1996a. Control strategies for citrus tristeza virus, In: A. Hadidi, R. K. Khetarpal, and H. Koganezawa (eds.). Plant Viral Disease Control: Principles and Practices. APS Press. St. Paul, MN.

[16] Gottwald, T.R., Polek, M. and Riley, K., 2002, February. History, present incidence, and spatial distribution of Citrus tristeza virus in the California Central Valley. In Proceedings of the 15th Conference of the International Organization of Citrus Virologists (pp. 83-94). Riverside, CA: IOCV.

[17] Li, F. and Ding, S.W., 2006. Virus counter defense: diverse strategies for evading the RNA-silencing immunity. Annu. Rev. Microbiol., 60, pp.503-531.

[18] Lucas, W.J., 2006. Plant viral movement proteins: agents for cell-to-cell trafficking of viral genomes. Virology, 344(1), pp.169-184.

[19] Marais, L.J., Marais, M.L. and Rea, M., 1996. Effect of citrus tristeza stem pitting on fruit size and yield of Marsh grapefruit in southern Africa. In Proc. 13th Conf. IOCV" (ed. da Graça, JV, Moreno, P. and Yokomi, RK) Univ. of Calif., Riverside, CA (pp. 163-167).

[20] Martelli, G. P., Sabanadzovic, S., Abou-GhanemSabanadzovic, N., Edwards, M. C., and Dreher, T., 2002. The family Tymoviridae. Arch. Virol. 147, 1837-1846.

[21] Martinez, A, Hermoso de Mendoza A, López A, Navarro L., 2000a. Incidence and epidemiology of Citrus

[22] Mekbib, S.B., 2007. Identification of citrus (Citrus sinensis) postharvest pathogens from Ethiopia and their control (Doctoral dissertation).

[23] Mohammed, Y., 2007. Distribution and management of Phaeoramularialeaf and fruit spot disease of citrus in Ethiopia. Fruits 62:99-106.

[24] Moreno P., S. Ambros, M.R. Albiach-Marti, J. Guerri and L. Pena, 2008. Plant diseases that changed the world citrustristeza virus: a pathogen that changed the course of the citrus industry. Molecular Plant Pathology ,9: 251-268

[25] Ng, J.C. and Falk, B.W., 2006. Virus-vector interactions mediating non persistent and semi persistent transmission of plant viruses. Annu. Rev. Phytopathol., 44, pp.183-212.

[26] Pretorius, M.C., Crous, P.W., Groenewald, J.Z. and Braun, U., 2003. Phylogeny of some cercosporoid fungi from Citrus. Sydowia, 55(2), pp.286-305.

[27] Qu, F, \& Morris, J., 2005. Suppressors of RNA silencing encoded by plant viruses and their role in viral infections. FEBS Letters. , 579, 5958-5964.

[28] Scholthof, H.B., 2005. Plant virus transport: motions of functional equivalence. Trends in plant science, 10(8), pp.376-382.

[29] Seifu, G. M., 2003. Status of commercial fruit production in Ethiopia. Ethiopian Agricultural Research Organization (EARO), Addis Ababa, Ethiopia.

[30] Sisay, B. M., 2007. Identification of citrus (Citrussinensis) postharvest pathogens from Ethiopia and their control. PhD Thesis, University of Pretoria, South Africa.

[31] Tatineni, S, Robertson, C, Garnsey, S. M, Bar-joseph, M, Gowda, S, \& Dawson, W. O., 2008. Three genes of Citrus tristeza virus are dispensable for infection and move-ment throughout some varieties of citrus trees. Virology. , 376(2), 297-307

[32] Tessega, K., Hussien, T. and Sakhuja, P.K., 2006. Management of phaeoramularia fruit and leaf spot disease of citrus in Ethiopia. Agriculturatropica et subtropica, 39(4), pp.241-247.

[33] Timmer, L. W, Garnsey S M, Graham J H., 2000. Compendium of Citrus Diseases. APS Press, St Paul, MNtristeza virus in the Valencian Community of Spain. Virus Research, 71, 85-95.

[34] Tsedeke, A., 2008. The identity and bionomics of insect vectors of tristeza and greening diseases of citrus in Ethiopia, Tropical Pest Management, 34:1, 19-23, 
[35] Voinnet, O., 2005. Induction \& suppression of RNA silencing: insights from viral in-fections. Nature Gen. Rev., 6, pp. 206-220.

[36] Waigmann, E., Ueki, S., Trutnyeva, K. and Citovsky, V., 2004. The ins and outs of nondestructive cell-tocell and systemic movement of plant viruses. Critical Reviews in Plant Sciences, 23(3), pp.195-250.

[37] Wang, M.B. and Metzlaff, M., 2005. RNA silencing and antiviral defense in plants. Current opinion in plant biology, 8(2), pp.216-222.

[38] Yokomi, R.K., Selvaraj, V., Maheshwari, Y., Saponari, M., Giampetruzzi, A., Chiumenti, M. and Hajeri, S., 2017. Identification and characterization of Citrus tristeza virus isolates breaking resistance in trifoliate orange in California. Phytopathology, 107(7), pp.901-908

Citation: Zenebe Wubshet, Dereje Amare, "Review on Citrus Triteza Virus" International Journal of Research Studies in Agricultural Sciences (IJRSAS), 2019; 5(4), pp. 25-36, http://dx.doi.org/10.20431/24546224.0504003

Copyright: (c) 2019 Authors. This is an open-access article distributed under the terms of the Creative Commons Attribution License, which permits unrestricted use, distribution, and reproduction in any medium, provided the original author and source are credited. 